Original Article

\title{
IN VITRO ANTI-DIABETIC AND ANTI-OXIDANT ACTIVITIES OF ETHANOL EXTRACT OF TINOSPORA SINENSIS
}

\author{
ANINDITA BANERJEE ${ }^{1}$, BITHIN MAJI ${ }^{1}$, SANDIP MUKHERJEE ${ }^{1}$, KAUSIK CHAUDHURI ${ }^{2}$, TAPAN SEAL ${ }^{2 *}$ \\ 1Department of Physiology, Serampore College, Hooghly, West Bengal, India, ${ }^{2}$ Plant Chemistry Department, Botanical Survey of India, \\ Howrah, India \\ Email: kaktapan65@yahoo.co.in
}

Received: 27 Nov 2016, Revised and Accepted: 23 Jan 2017

\begin{abstract}
Objective: The aim of the present study was to evaluate the alpha $(\alpha)$-amylase and alpha $(\alpha)$-glucosidase inhibitory activities and in vitro antioxidant activities of the $80 \%$ aqueous ethanol extracts of Tinosporasinensis Lour (Merr.).

Methods: The $80 \%$ aq. ethanol extract of the plant was prepared. The plant extract was examined for its antioxidant activity by using free radical 1,1-diphenyl-2-picryl hydrazyl (DPPH) scavenging method, ABTS radical scavenging ability, reducing power capacity, estimation of total phenolic content, flavonoid content and flavonol content. Different concentrations $(2,4,8,10$ and $15 \mu \mathrm{g} / \mathrm{ml})$ of the extract was subjected to $\alpha$-amylase
\end{abstract} inhibitory and $\alpha$-glucosidase inhibitory activities and IC ${ }_{50}$ were calculated.

Results: The study revealed that the different concentrations of the plant extract possessed a very good amount of total phenolics, flavonoid and flavonol and exhibited potent radical scavenging activity using DPPH and ABTS as a substrate. The ethanol extracts exhibited significant $\alpha$-amylase and

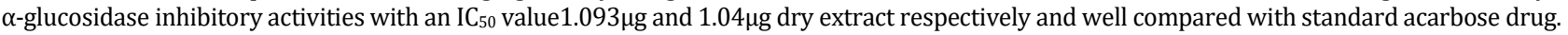

Conclusion: Thus, it could be concluded that due to the presence of antioxidant components the plant extracts could be used for the treatment of hyperglycemia, diabetes and the related condition of oxidative stress. This knowledge will be useful in finding more potent components from the natural resources for the clinical development of antidiabetic therapeutics.

Keywords: Tinosporasinensis, $80 \%$ aq. ethanol extract, Antioxidant activities, $\alpha$-amylase inhibitory activity, $\alpha$-glucosidase inhibitory activity

(C) 2016 The Authors. Published by Innovare Academic Sciences Pvt Ltd. This is an open access article under the CC BY license (http://creativecommons.org/licenses/by/4.0/) DOI: http://dx.doi.org/10.22159/ijcpr.2017v9i2.17379

\section{INTRODUCTION}

Diabetes mellitus is an important chronic metabolic disorder that affects the digestion of carbohydrate, fat and protein. It includes a group of metabolic diseases characterised by hyperglycemia, in which blood sugar levels are elevated either because the pancreas does not produce enough insulin or cells throughout the body do not respond properly to the insulin produced. The effects of diabetes mellitus include long-term complications include heart disease, stroke, dysfunction and failure of various organs [1].

There are three forms of diabetes. The three main kinds of diabetes are type 1 , type 2 , and gestational diabetes. Both women and men can develop diabetes at any age. The type 1 diabetes includes the cases which can be attributed to an autoimmune process and/or those with $\beta$-cell destruction for which unknown pathogenesis. Type 2 includes the common major form of diabetes, which results from defects in insulin secretion or rather insulin resistance. Gestational diabetes can develop to a pregnant woman when a pancreas does not make enough insulin during gestation.

The only therapy of type 1 diabetes is the substitution of insulin. Many and diverse therapeutic strategies for the treatment of type 2 diabetes are known. The conventional treatments for diabetes include the reduction of the demand for insulin, stimulation of endogenous insulin secretion, enhancement of the action of insulin at the target tissues and the inhibition of degradation of oligo-and disaccharides [2-3].

One group of drugs introduced into the management of type 2 diabetes is represented by the inhibitors of $\alpha$-glucosidase. The enzymes summarised as $\alpha$-glucosidase is responsible for the breakdown of oligo and/or disaccharides to monosaccharides. The inhibitory action of these enzymes leads to a decrease of the blood glucose level because the monosaccharides are the form of carbohydrates which is absorbed through the mucosal border in the small intestine.
Another effective method to control diabetes is to inhibit the activity of a $\alpha$-amylase enzyme which is responsible for the breakdown of starch to simpler sugars (dextrin, maltotriose, maltose and glucose) [4]. This is contributed by $\alpha$-amylase inhibitors, which delays the glucose absorption rate thereby maintaining the serum blood glucose in hyperglycemic individuals [5].

Some inhibitors currently in clinical use are acarbose and miglitol which inhibit glycosidases such as $\alpha$-glucosidase and $\alpha$-amylase while others such as and voglibose inhibit $\alpha$-glucosidase. However, many of these synthetic hypoglycemic agents have their limitations, are non-specific, produce serious side effects and fail to elevate diabetic complications. The main side effects of these inhibitors are gastrointestinal viz., bloating, abdominal discomfort, diarrhea and flatulence [6]. Recently herbal medicines have acquired more importance in the treatment of diabetes as they are free from side effects and less expensive when compared to synthetic hypoglycemic agents [7-8].

Various plants such as Proteus vulgaris, Euphorbia hirta, Cassia glauca containing active constituents like saponin, phenols, flavonoids, etc showed potential $\alpha$-amylase inhibitors [9]. The role of medicinal plants in disease prevention is attributed to its antioxidant properties due to their bioactive constituents [10].

Tinosporasinensis (Lour.) Merrbelongs to the family Menispermaceae and the stem of the plant are used as medicine. The plant grows wild in most parts of India, both in forests and plains. The plant is reported to be used for fumigation in piles and ulcerated wounds, and for the preparation of medicated baths for liver complaints. The boiled roots are given in fever. Fresh leaves and stems are used in chronic rheumatism and also a muscle relaxant [11].

Thus, in this study, the antioxidant and antidiabetic activities of the $80 \%$ aq. ethanol extract from the stem of $T$. sinensis was carried out and a relationship of these activities was established. To evaluate the 
potential of $T$. sinensis stem extract as antidiabetic agents, we investigated the effect of extracts on the $\alpha$-glucosidase and $\alpha$ amylase inhibitory activities.

\section{MATERIALS AND METHODS}

\section{Plant materials}

The stem of Tinospora sinensis was collected from Hooghly district West Bengal, India and authenticated from Botanical Survey of India, Howrah. The voucher specimens were preserved in our department under registry no PHYSIOL/BM/AB 001. The plant parts were sheddried, pulverised and stored in an airtight container for further extraction.

\section{Chemicals}

Alpha $(\alpha)$-Glucosidase, porcine pancreas alpha $(\alpha)$-amylase, $p$ nitrophenyl- $\alpha$-D-glucopyranose ( $p$-NPG), 3,5-dinitrosalicylic acid (DNS),1,1-Diphenyl-2-picrylhydrazyl (DPPH), 2,2'-azino-bis(3-ethyl benzothiazoline-6-sulfonic acid) (ABTS), butylated hydroxytoluene (BHT), gallic acid, rutin, quercetin, ascorbic acid and acarbose were purchased from Sigma Chemical Co. (St. Louis, MO, USA). Soluble starch, sodium potassium tartarate, sodium dihydrogen phosphate $\left(\mathrm{NaH}_{2} \mathrm{PO}_{4}\right)$, Di-sodium hydrogen phosphate $\left(\mathrm{Na}_{2} \mathrm{HPO}_{4}\right)$ sodium chloride, sodium hydroxide, butylated hydroxytoluene (BHT), potassium persulfate, sodium carbonate, Folin-Ciocalteu (FC) reagent, potassium ferricyanide, potassium per sulphate, aluminum chloride, ferric chloride $\left(\mathrm{FeCl}_{3}\right)$ were from Merck Chemical Supplies (Damstadt, Germany). All the chemicals used including the solvents were of analytical grade.

\section{Extraction of plant material}

The air-dried and coarse powdered plant sample of T. sinensis (10 g) was extracted with $100 \mathrm{ml} 80 \%$ aq. ethanol by maceration on an orbital shaker with agitation for five days at room temperature. The extract was filtered and the residue was again extracted with the same solvent for another five days and filtered. The filtered extracts were combined and concentrated using a rotary evaporator, under reduced pressure at approximately $40{ }^{\circ} \mathrm{C}$ and lyophilized to obtain the powdered extract. The powdered extracts were analysed for their $\alpha$ glucosidase and $\alpha$-amylase inhibition assays. The total phenolic, flavonoid and flavonol content, reducing power and their free radical scavenging capacity of the ethanol extracts from the plant were also investigated.

\section{Estimation of total phenolic content}

The amount of total phenolic content of crude extracts was determined according to Folin-Ciocalteu procedure [12]. The tested extracts $(100 \mathrm{ml})$ were introduced into test tubes. $1.0 \mathrm{ml}$ of FolinCiocalteu reagent and $0.8 \mathrm{ml}$ of sodium carbonate $(7.5 \%)$ were added. The tubes were mixed and allowed to stand for $30 \mathrm{~min}$. Absorption at $765 \mathrm{~nm}$ was measured (UV-visible spectrophotometer Shimadzu UV 1800).

\section{Estimation of total flavonoids}

Total flavonoids were estimated using the method of Ordonez et al, 2006[13]. To $0.5 \mathrm{ml}$ of extracts, $0.5 \mathrm{ml}$ of $2 \% \mathrm{AlCl} 3$ ethanol solution was added. After one hour, at room temperature, a yellow color developed, indicated the presence of flavonoids and the absorbance was measured at $420 \mathrm{~nm}$ (UV-visible spectrophotometer Shimadzu UV 1800).

\section{Estimation of total flavonols}

Total flavonols in the plant extracts were estimated using the method of Kumaran and Karunakaran, 2006 [14]. To $1.0 \mathrm{ml}$ of extracts $1.0 \mathrm{ml}$ of $2 \% \mathrm{AlCl}_{3}$ ethanol and $3.0 \mathrm{ml}(50 \mathrm{~g} / \mathrm{l})$ sodium acetate solutions were added. The absorption at $440 \mathrm{~nm}$ (UV-visible spectrophotometer Shimadzu UV 1800) was read after $2.5 \mathrm{~h}$ at $20^{\circ} \mathrm{C}$ for the estimation of total flavonol content in the plant extract.

\section{Measurement of reducing power}

The reducing power of the extracts was determined according to the method of Oyaizu, 1986 [15]. The plant extracts $(100 \mu \mathrm{l})$ were mixed with phosphate buffer $(2.5 \mathrm{ml}, 0.2 \mathrm{M}, p \mathrm{H} 6.6)$ and $1 \%$ potassium ferricyanide $(2.5 \mathrm{ml})$. The mixture was incubated at $50^{\circ} \mathrm{C}$ for $20 \mathrm{~min}$. Aliquots of $10 \%$ trichloroacetic acid $(2.5 \mathrm{ml})$ were added to the mixture, which was then centrifuged at $3000 \mathrm{rpm}$ for $10 \mathrm{~min}$. The upper layer of the solution $(2.5 \mathrm{ml})$ was mixed with distilled water $(2.5 \mathrm{ml})$ and a freshly prepared ferric chloride solution $(0.5 \mathrm{ml}$, $0.1 \%$ ). The absorbance was measured at $700 \mathrm{~nm}$ and reducing power is determined.

\section{Determination of DPPH free radical scavenging activity}

The free radical scavenging activity of the plant extract and butylated hydroxyl toluene (BHT) as a positive control was determined using the stable radical DPPH (1,1-diphenyl-2-picrylhydrazyl) [16]. Aliquots (20, 40 and $80 \mathrm{ml}$ ) of the tested extracts were placed in test tubes and 3.9 $\mathrm{ml}$ of freshly prepared DPPH solution $\left(25 \mathrm{mg} \mathrm{L}^{-1}\right)$ in methanol was added in each test tube and mixed. 30 min later, the absorbance was measured at $517 \mathrm{~nm}$ (UV-visible spectrophotometer Shimadzu UV 1800). The capability to scavenge the DPPH radical was calculated, using the following equation:

$$
\text { DPPH scavenged }(\%)=\{(\mathrm{Ac}-\mathrm{At}) / \mathrm{Ac}\} \times 100
$$

Where Ac is the absorbance of the control reaction and At is the absorbance in the presence of the sample of the extracts. The antioxidant activity of the extract was expressed as $\mathrm{IC}_{50}$. The $\mathrm{IC}_{50}$ value was defined as the concentration in mg of dry material per $\mathrm{ml}$ $(\mathrm{mg} / \mathrm{ml})$ that inhibits the formation of DPPH radicals by $50 \%$. Each value was determined from the regression equation.

\section{Determination of scavenging activity of ABTS radical cation}

The 2,2'-azino-bis(3-ethylbenzothiazoline-6-sulfonic acid) (ABTS) radical cation (ABTS.+)-scavenging activity was measured according to the method described by Re et al.[17]. ABTS was dissolved in water to a $7 \mathrm{mmol}$ concentration. The ABTS radicals were produced by adding $2.45 \mathrm{mmol}$ potassium persulphate(final concentration). The completion of radical generation was obtained in the dark at room temperature for 12-16 h. This solution was then diluted with ethanol to adjust its absorbance at $734 \mathrm{~nm}$ to $0.70 \pm 0.02$. To determine the scavenging activity, $1 \mathrm{ml}$ of diluted ABTS.+solution was added to 20,40 and $80 \mu \mathrm{l}$ of plant extracts and the absorbance at $734 \mathrm{~nm}$ was measured 6 min after the initial mixing, using ethanol as the blank. The percentage of inhibition was calculated by the equation:

$$
\text { ABTS scavenged }(\%)=\left(A_{\text {cont }}-A_{\text {test }}\right) / A_{\text {cont }} \times 100
$$

where $A_{c}$ and $A_{s}$ are the absorbencies of the control and of the test sample, respectively. From a plot of concentration against \% inhibition, a linear regression analysis was performed to determine the $\mathrm{IC}_{50}$ value of the plant extract.

\section{In vitro $\alpha$-amylase inhibitory assay}

The $\alpha$-amylase enzyme solution was prepared by mixing $27.5 \mathrm{mg}$ of porcine pancreatic amylase (PPA) in $100 \mathrm{ml} 20 \mathrm{mmol}$ of phosphate buffer (pH 6.9) containing $6.7 \mathrm{mmol}$ of sodium chloride. To $100 \mu \mathrm{l}$ of $(2,4,8,10,15 \mu \mathrm{g} / \mathrm{ml})$ plant extracts, $200 \mu \mathrm{l}$ PPA solution was added and the mixture was incubated at $37^{\circ} \mathrm{c}$ for $20 \mathrm{~min}$. To the reaction mixture $100 \mu \mathrm{l}(1 \%)$ starch solution (A starch solution $(1 \% \mathrm{w} / \mathrm{v})$ was prepared by stirring $1 \mathrm{~g}$ starch in $100 \mathrm{ml}$ of $20 \mathrm{mmol}$ of phosphate buffer $(\mathrm{pH}$ 6.9) containing $6.7 \mathrm{mmol}$ of sodium chloride) was added and incubated at $37^{\circ} \mathrm{C}$ for $10 \mathrm{~min}$. The reaction was stopped by adding 200 $\mu \mathrm{l}$ DNSA (1g of 3,5 di-nitro salicylic acid, 30g of sodium potassium tartarate and $20 \mathrm{ml}$ of $2 \mathrm{~N}$ sodium hydroxide was added and made up to a final volume of $100 \mathrm{ml}$ with distilled water) and kept it in a boiling water bath for $5 \mathrm{~min}$. The reaction mixture diluted with $2.2 \mathrm{ml}$ of water and absorbance was read at $540 \mathrm{~nm}$.

For each concentration, blank tubes were prepared by replacing the enzyme solution with $200 \mu \mathrm{L}$ in distilled water. Control, representing $100 \%$ enzyme activity was prepared in a similar manner, without extract. The experiments were repeated thrice using the same protocol [18].

\section{In vitro $\alpha$-glucosidase inhibition assay}

The inhibition of $\alpha$-glucosidase activity was determined using the modified published method [19]. One mg of $\alpha$-glucosidase was 
dissolved in $100 \mathrm{ml} 20 \mathrm{mmolof}$ phosphate buffer (pH 6.8). To $100 \mu \mathrm{l}$ of $(2,4,8,10,15 \mu \mathrm{g} / \mathrm{ml})$ plant extracts, $200 \mu \mathrm{l} \alpha$-glucosidase were added and the mixture was incubated at $37{ }^{\circ} \mathrm{C}$ for $20 \mathrm{~min}$. To the reaction mixture $100 \mu \mathrm{l} 3 \mathrm{mmol} p$-nitrophenyl $\alpha$-D-glucopyranoside ( $p$-NPG) was added and incubated at $37{ }^{\circ} \mathrm{C}$ for $10 \mathrm{~min}$. The reaction was terminated by the addition of $2 \mathrm{ml} \mathrm{Na} \mathrm{CO}_{3}(0.1 \mathrm{M})$ and the $\alpha$ glucosidase inhibitory activity was determined spectrophotometrically at $405 \mathrm{~nm}$ on spectrophotometer UV-VIS (Shimadzu UV-1800) by measuring the quantity of $p$-nitrophenol released from $p$-NPG.

Acarbose was used as positive control of $\alpha$-amylase and $\alpha$ glucosidase inhibitor. The concentration of the extract required to inhibit $50 \%$ of $\alpha$-amylase and $\alpha$-glucosidase activity under the assay conditions was defined as the $\mathrm{IC}_{50}$ value.

\section{Method for calculation of $\alpha$-amylase and $\alpha$-glucosidase} inhibitory concentration (IC50)

The concentration of the plant extracts required to scavenge $50 \%$ of the radicals (IC50) was calculated by using the percentage scavenging activities at five different concentrations of the extract. Percentage inhibition (I \%) was calculated by

$$
\mathrm{I} \%=(\text { Ac-As }) / \text { Ac X 100, }
$$

Where Ac is the absorbance of the control and As is the absorbance of the sample [20].

Values are presented as mean \pm standard error mean of three replicates. The total phenolic content, flavonoid content, flavonol content, reducing power and $\mathrm{IC}_{50}$ value of each plant material was calculated by using Linear Regression analysis.

\section{RESULTS AND DISCUSSION}

The results showed that the ethanol extract of the plant exhibited good antioxidant property and dose-dependent $\alpha$-amylase and $\alpha$ glucosidase inhibitory activities by in vitro assay using starch and $p$ NPG respectively as substrate.

\section{Total phenol, flavonoid and flavonol content of the extracts}

Polyphenols have been said to be important phytochemicals with significant antioxidant capacities and other potent medicinal characteristics. Total phenolic content in the plant extract was determined by the FC method and the calibration curve developed using Gallic acid. A regression equation was obtained from the standard curve and the amount of Gallic acid in the ethanol extract of T. sinensis was calculated from the regression equation: $\mathrm{y}=$ $0.0013 \mathrm{x}+0.0498, \mathrm{R}^{2}=0.999$ where $\mathrm{y}$ was the absorbance and $\mathrm{x}$ was the Gallic acid equivalent (mg/g).

The investigation showed that the plant under study contained a very good amount of total phenolics $(18.18 \pm 0.09 \mathrm{mg} \mathrm{GAE} / \mathrm{mg}$ plant extracts) which is well compared with the extract of Terminalia arjuna (20.862 mg GAE/g plant extracts)[21].

Total flavonoid content in the plant extract was calculated as rutin $(\mathrm{mg} / \mathrm{g})$ equivalent using the equation based on the calibration curve: $\mathrm{y}=0.0182 \mathrm{x}-0.0222, \mathrm{R}^{2}=0.9962$, where $\mathrm{y}$ was the absorbance and $\mathrm{x}$ was the rutin equivalent $(\mathrm{mg} / \mathrm{g})$ and the flavonol content in the plant extract was estimated as quercetin $(\mathrm{mg} / \mathrm{g}$ ) equivalent using the equation based on the calibration curve: $\mathrm{y}=$ $0.0049 x+0.0047, R^{2}=0.9935$, where $y$ was the absorbance and $x$ was the quercetin equivalent $(\mathrm{mg} / \mathrm{g})$. The experimental result showed the presence of an appreciable amount of flavonoid $0.35 \pm 0.005 \mathrm{mg} / \mathrm{gm})$ and flavonol $(0.31 \pm 0.012 \mathrm{mg} / \mathrm{gm})$ in the ethanol extract of $T$. sinensis.

The result of investigation also showed a very good reducing power $(0.52 \pm 0.006 \mathrm{mg} / \mathrm{gm}$ dry extract) with the ethanol extract of the plant. The reducing power of the extract was evaluated in ascorbic acid equivalent (AAE) in milligram per gram $(\mathrm{mg} / \mathrm{g})$ of dry extract using the following equation based on the calibration curve: $\mathrm{y}=$ $0.0023 \mathrm{x}-0.0063, \mathrm{R}^{2}=0.9955$ where $\mathrm{y}$ was the absorbance and $\mathrm{x}$ was the ascorbic acid equivalent (mg/g).

It has been established that phenolic compounds are the major plant compounds with antioxidant activity and this activity is due to their redox properties. Phenolic compounds are a class of antioxidant agents which can adsorb and neutralise the free radicals [22].

Flavonoids and flavonols are considered as one of the most widespread groups of natural constituents found in the plants. It has been recognised that both flavonoids and flavonols show antioxidant activity through scavenging or chelating process [23].

Table 1: Antioxidant activities of the $80 \%$ aq. ethanol extract of $T$. sinensis

\begin{tabular}{|c|c|c|c|c|c|c|}
\hline $\begin{array}{l}\text { Name of } \\
\text { the plant }\end{array}$ & $\begin{array}{l}\text { Total } \\
\text { phenolic } \\
\text { content } \\
\text { (GAE mg/g } \\
\text { dry extract) }\end{array}$ & $\begin{array}{l}\text { Total flavonoid } \\
\text { content } \\
\text { (Rutin equivalent } \\
\text { mg/g dry } \\
\text { extract) }\end{array}$ & $\begin{array}{l}\text { Total flavonol } \\
\text { content } \\
\text { (Quercetin } \\
\text { equivalent } \mathrm{mg} / \mathrm{g} \\
\text { dry extract) } \\
\end{array}$ & $\begin{array}{l}\text { Reducing power } \\
\text { (Ascorbic acid } \\
\text { equivalent } \mathrm{mg} / \mathrm{g} \\
\text { dry extract) }\end{array}$ & $\begin{array}{l}\text { Free radical } \\
\text { scavenging ability } \\
\text { (DPPH) } \\
\text { (IC } 50 \mathrm{mg} / \mathrm{g} \text { dry } \\
\text { extract) }\end{array}$ & $\begin{array}{l}\text { Free radical } \\
\text { scavenging ability } \\
\text { (ABTS) } \\
\text { (IC } \mathrm{I}_{50} \mathrm{mg} / \mathrm{g} \text { dry } \\
\text { extract) }\end{array}$ \\
\hline T. sinensis & $18.18 \pm 0.09$ & $0.17 \pm 0.002$ & $0.24 \pm 0.004$ & $0.30 \pm 0.005$ & $0.72 \pm 0.005$ & $0.32 \pm 0.001$ \\
\hline
\end{tabular}

Each value in the table was obtained by calculating the average of three experiments and data are presented as mean \pm SEM

The results strongly suggest that phenolics are important components of these plants. The other phenolic compounds such as flavonoids, flavonols, which contain hydroxyls are also responsible for the radical scavenging effect in the plants.

Thus after determining the total phenol content of the plants, the antioxidant activities of the plants were estimated for their free radical scavenging activity.

The evaluation of anti-radical properties of the ethanol extract of $T$. sinensis was executed by DPPH radical scavenging assay. The $50 \%$ inhibition of DPPH radical $\left(\mathrm{IC}_{50}\right)$ by the plant extract was determined (table 1), a lower value would reflect the greater antioxidant activity of the sample. DPPH stable free radical method is an easy, rapid and sensitive way to survey the antioxidant activity of a specific compound or plant extracts [24]. The antioxidant effect is proportional to the disappearance of the purple colour of DPPH in test samples. Thus antioxidant molecules can quench DPPH free radicals by providing hydrogen atom or by electron donation and a colourless stable molecule 2,2-diphenyl-1-hydrazine is formed and as a result of which the absorbance (at $517 \mathrm{~nm}$ ) of the solution is decreased.

Hence the more potent antioxidant, more decrease in absorbance is seen and consequently, the $\mathrm{IC}_{50}$ value will be minimum. In the present study, the potent radical scavenging activity $\left(\mathrm{IC}_{50}=\right.$ $0.72 \pm 0.005 \mathrm{mg} / \mathrm{gm}$ dry ext) was shown by the $80 \%$ aq. ethanol extract of T. sinensis.

The antioxidant activity of the ethanol extract of $T$. sinensis using ABTS assay was also carried out. The antioxidant effect is proportional to the disappearance of the colour of ABTS in test samples. The concentration of sample that could scavenge $50 \%$ free radical $\left(\mathrm{IC}_{50}\right)$ was used to determine antioxidant capacity of the sample compared to standard. The sample that had $\mathrm{IC}_{50}<50 \mathrm{ppm}$, it was a very strong antioxidant, 50-100 ppm strong antioxidant, 101$150 \mathrm{ppm}$ medium antioxidant, while weak antioxidant with $\mathrm{IC}_{50}>150$ $\mathrm{ppm}$. A strong inhibition was observed $\left(\mathrm{IC}_{50}=0.32 \pm 0.001 \mathrm{mg} / \mathrm{gm}\right.$ dry ext) with the $80 \%$ aq. ethanol extract of the plant under investigation. 


\section{In vitro $\alpha$-amylase inhibitory assay}

$\alpha$-amylaseis one of the key enzymes that play a role in digestion of starch and glycogen and carbohydrate metabolism. Its inhibition is one of the strategies for the treatment of disorders in carbohydrate uptake, such as diabetes and obesity. It is involved in carbohydrate metabolism and thus inhibiting it would lead to reduced post prandial blood sugar [25].

A number of medicinal plants and their formulations are used for treating diabetes in the traditional Indian Ayurvedic system as well as in ethnomedicinal practices as their principal bioactive components showed good $\alpha$-amylase inhibitory and antioxidant properties [26].

The result of the present experiment showed that there was a dosedependent increase in percentage inhibitory activity against the $\alpha$ - amylase enzyme. The $80 \%$ aq. ethanol extract $(2-15 \mu \mathrm{g} / \mathrm{ml})$ of $T$. sinensis exhibited potent $\alpha$-amylase inhibitory activity in a dose dependent manner. The $80 \%$ aq. ethanol extract of the plant showed inhibitory activity from $2.07 \pm 0.06$ to $13.87 \pm 0.05 \%$ with an $\mathrm{IC}_{50}$ value of $1.093 \mu \mathrm{g}$ dry extract (table 2 ).

Acarbose is a standard drug for the $\alpha$-amylase inhibitor. Acarbose at a concentration of $(2-15 \mu \mathrm{g} / \mathrm{ml})$ showed $\alpha$-amylase inhibitory activity from $6.99 \pm 0.03$ to $56.17 \pm 0.05 \%$ with an $\mathrm{IC}_{50}$ value $0.32 \mu \mathrm{g}$ dry extract. A comparison of $\alpha$-amylase inhibitory activity between the standard drug and plant extracts has been depicted in fig. 1 . So the ethanol extract of $T$. sinensis might be used as starch blockers since it prevents or slows the absorption of starch in to the body mainly by blocking the hydrolysis of 1,4-glycosidic linkages of starch and other oligosaccharides into maltose, maltriose and other simple sugars.

Table 2: In vitro antidiabetic activity of the $80 \%$ aq. ethanol extract of $T$. sinensis using alpha amylase method and comparison with standard drug acarbose

\begin{tabular}{|c|c|c|c|c|}
\hline S. No. & Plant extract/standard drug & $\begin{array}{l}\text { Concentration } \\
\mu \mathrm{g} / \mathrm{ml}\end{array}$ & $\%$ of Inhibition & $\begin{array}{l}\text { IC } 50 \\
\mu g \text { dry extract }\end{array}$ \\
\hline \multirow[t]{5}{*}{1} & $80 \%$ aq. ethanol extract of $T$. sinensis & 2 & $2.07 \pm 0.06$ & 1.093 \\
\hline & & 4 & $4.80 \pm 0.02$ & \\
\hline & & 8 & $8.85 \pm 0.04$ & \\
\hline & & 10 & $10.27 \pm 0.08$ & \\
\hline & & 15 & $13.87 \pm 0.05$ & \\
\hline \multirow[t]{5}{*}{2} & Acarbose & 2 & $6.99 \pm 0.03$ & 0.32 \\
\hline & & 4 & $11.58 \pm 0.05$ & \\
\hline & & 8 & $26.45 \pm 0.02$ & \\
\hline & & 10 & $41.64 \pm 0.06$ & \\
\hline & & 15 & $56.17 \pm 0.05$ & \\
\hline
\end{tabular}

Each value in the table was obtained by calculating the average of three experiments and data are presented as mean \pm SEM

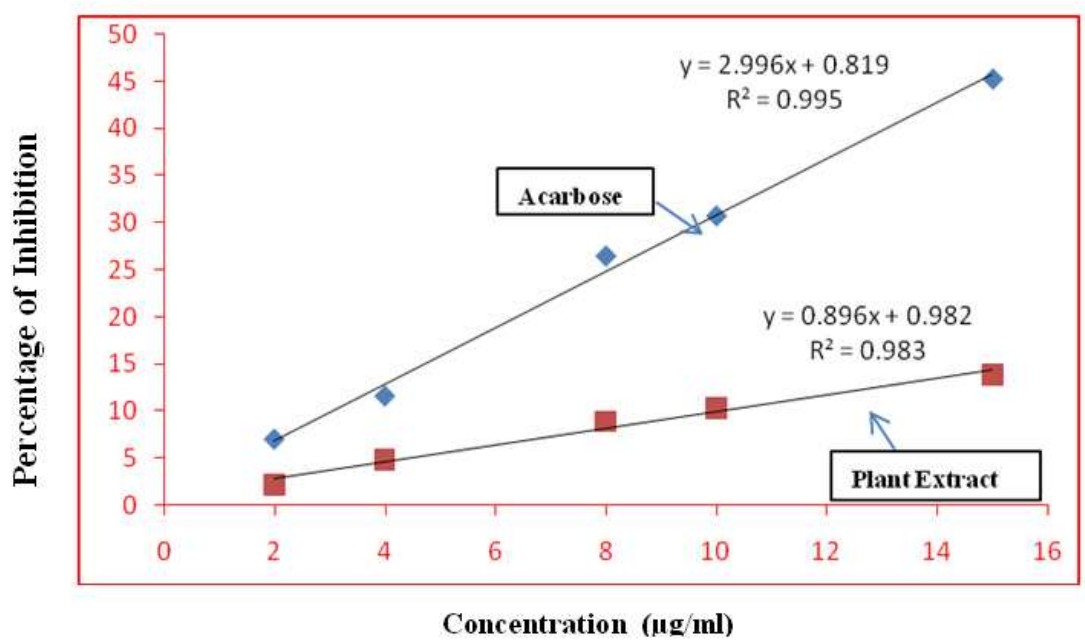

Fig. 1: $\alpha$-amylase inhibitory activity of acarbose vs $80 \%$ aq. ethanol extract of $T$. Sinensis

In our study, the ethanol extract of the plant showed maximum $\alpha$ amylase inhibitory activity ( IC $_{50}=1.093 \mu \mathrm{g}$ dry extract) which could be attributed to the presence of polyphenols $(18.18 \pm 0.09 \mathrm{mg} / \mathrm{g})$ and flavonoids $(0.17 \pm 0.002)$ because polyphenols are not only capable of reducing oxidative stress but also of inhibiting carbohydrate hydrolyzing enzymes because of their ability to bind with proteins [1].

Our results are in accordance with the previous study wherein; there is a positive relationship between the total polyphenol and flavonoid content and the ability to inhibit intestinal $\alpha$-glucosidase and pancreatic $\alpha$-amylase [27-28].

\section{In vitro $\alpha$-glucosidase inhibitory assay}

$\alpha$-glucosidase enzyme located in the brush border of the small intestine. It breaks down starch and disaccharides to glucose. $\alpha$ - glucosidase inhibitors are oral anti-diabetic drugs used for diabetes mellitus type 2 that work by inhibiting the digestion of carbohydrates (such as starch and table sugar). Carbohydrates are normally converted into simple sugars (monosaccharides), which can be absorbed through the intestine. Hence, $\alpha$-glucosidase inhibitors reduce the impact of carbohydrates on blood sugar. $\alpha$-glucosidase inhibitors from natural sources have received tremendous attention because of the highly abundant compounds in nature and their promising biological activities. On the basis of literatures published worldwide, it has been established that natural products isolated from medicinal plants showed potent $\alpha$-glucosidase inhibitory activity.

Structurally these natural product inhibitors includes terpene, alkaloid, quinine, flavonoid, phenol, phenylpropanoid, and steride frameworks rich in organic acid, ester, alcohol, and allyl functional 
groups. A majority of the compounds reported contain flavonoid, terpene, and phenylpropanoid ring structures [29].

The results of antidiabetic activity using $\alpha$-glucosidase inhibitory assay of the $80 \%$ aq. ethanol extracts of $T$. sinensisstem are shown in table 3. The extract revealed a significant inhibitory action of $\alpha$ glucosidase enzyme. The percentage inhibition at $2-15 \mu \mathrm{g} / \mathrm{ml}$ concentrations of $T$. sinensis extract showed a dose dependent increase in percentage inhibition. The percentage inhibition varied from $17.89 \pm 0.11 \%-6.50 \pm 0.09 \%$ for highest concentration to the lowest concentration.

Thus the inhibition of the activity of $\alpha$-glucosidase by T. sinensis would delay the degradation of carbohydrate, which would in turn cause a decrease in the absorption of glucose, as a result the reduction of postprandial blood glucose level elevation [30].

Table 3: In vitro antidiabetic activity of the $80 \%$ aq. ethanol extract of $T$. sinensis using alpha-glucosidase method and comparison with standard drug acarbose

\begin{tabular}{llll}
\hline S. No. & Plant extract/standard drug & Concentration $\boldsymbol{\mu g} / \mathbf{m l}$ & \% of Inhibition \\
\hline 1 & $80 \%$ aq. ethanol extract of $T$. sinensis & 2 & $6.50 \pm 0.09$ \\
& 4 & $10.43 \pm 0.07$ \\
& 8 & $13.11 \pm 0.12$ \\
& & 10 & $15.31 \pm 0.09$ \\
2 & 15 & $17.89 \pm 0.11$ \\
& Acarbose & 2 & $29.57 \pm 0.14$ \\
& 4 & $31.58 \pm 0.17$ \\
& 8 & $34.93 \pm 0.12$ \\
\end{tabular}

Each value in the table was obtained by calculating the average of three experiments and data are presented as mean \pm SEM

A comparison of $\alpha$-glucosidase inhibitory activity between the standard drug and plant extracts has been depicted in fig. 2 .

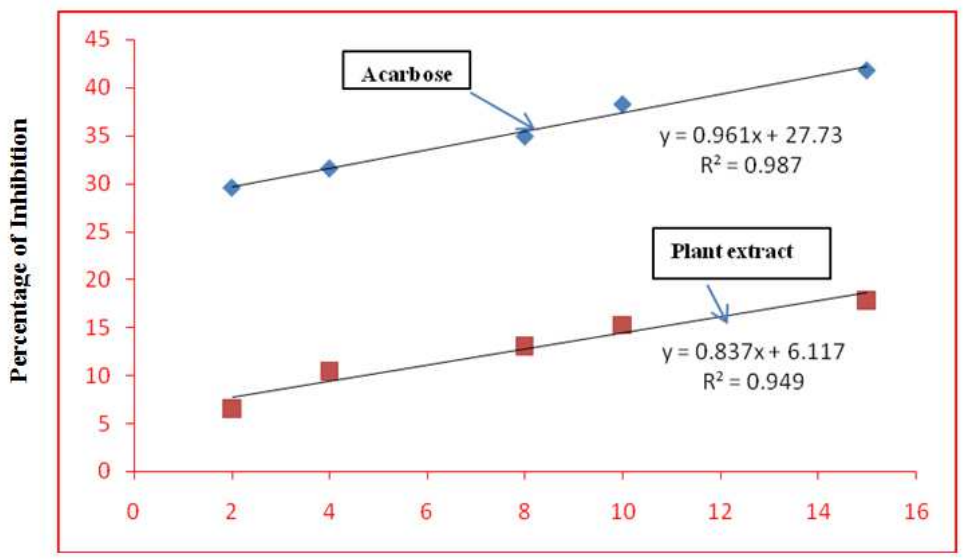

Concentration $(\mu \mathrm{g} / \mathrm{ml})$

Fig. 2: $\alpha$-Glucosidase inhibitory activity of Acarbose vs $80 \%$ aq. ethanol extract of $T$. Sinensis

In this study, acarbose was also used as a standard drug for the $\alpha$ glucosidase inhibitor. Acarbose at a concentration of $(2-15 \mu \mathrm{g} / \mathrm{ml})$ showed $\alpha$-glucosidase inhibitory activity from $29.57 \pm 0.14$ to $41.82 \pm 0.08 \%$ with an $\mathrm{IC}_{50}$ value $0.46 \mu \mathrm{g}$ dry extract.

This indicates that the ethanolic extract of $T$. sinensis is very potent $\alpha$-amylase and $\alpha$-glucosidase inhibitor in comparison with acarbose. This could be justified that the nature of some extract constituents (phenols, flavonoids saponins, steroids, alkaloids, terpenoids) present in the extract could be responsible as being effective inhibitors of $\alpha$-amylase and $\alpha$-glucosidase.

\section{CONCLUSION}

To investigate the biological activities of $T$. sinensis tuberous stem, the antioxidant and antidiabetic activities of the $80 \%$ ethanol extract of the plant has been analysed. As a result, we found that the extract of $T$. sinensis have free radical scavenging activity and inhibitory activity against $\alpha$-amylase and $\alpha$-glucosidase and this therapeutic potentiality could be exploited in the management of postprandial hyperglycemia in the treatment of type 2 diabetes mellitus. Although the effects of $T$. sinensis extract have been established in vitro, these results indicate that $T$. sinensis has potential as a crude drug and a dietary health supplement.
The plant showed significant enzyme inhibitory activity, so the compound isolation, purification and characterization which is responsible for inhibiting activity, has to be done for the usage of antidiabetic agent. Further studies are also required to elucidate whether the plant have antidiabetic potential by in vivo for corroborating the traditional claim of the plant.

\section{ACKNOWLEDGEMENT}

Authors of this paper are highly grateful to Dr. P. Singh, Director, Botanical Survey of India, Kolkata, for providing all facilities. We are also thankful to Dr. R. Gogoi, Scientist D, Botanical Survey of India, Howrah for identifying the plant specimens.

\section{CONFLICT OF INTERESTS}

None declared conflict of interest

\section{REFERENCES}

1. Keerthana G, Kalaivani MK, Sumathy A. In vitro alpha-amylase inhibitory and antioxidant activities of an ethanolic leaf extract of Croton bonplandianum. Asian J Pharm Clin Res 2013;6:32-6.

2. Groop L, Forsblom C, Lehtovirta M. Characterization of the prediabetic state. Am J Hypertens 1997;10:172-80. 
3. Perfetti R, Barnett PS, Mathur R, Egan JM. Novel therapeutic strategies for the treatment of type 2 diabetes. Diabetes Metab Rev 1998;14:207-25.

4. Alexander R. Maltodextrins: production, properties and applications. In: Schenk F, Hebeda R. ed. Starch hydrolysis products; worldwide technology: production and applications, New York; 1992. p. 62-122.

5. Dineshkumar B, Mitra A, Manjunatha M. A comparative study of alpha-amylase inhibitory activities of common antidiabetic plants of Kharagpur 1 block. Int J Green Pharm 2010;4:115-21.

6. Cheng AYY, FantusI G. Oral antihyperglycemic therapy for type 2 diabetes mellitus. Canadian Med Assoc J 2005;172:213-26.

7. Grover JK, Yadav S, Vats V. Medicinal plants of India with antidiabetic potential. J Ethnopharmacol 2002;81:81-100.

8. Mukherjee PK, Maiti K, Mukherjee K, Houghton PJ. Leads from Indian medicinal plants with hypoglycemic potentials. J Ethnopharmacol 2006;106:1-28.

9. Sunil K, Rashmi Kumar D. Evaluation of antidiabetic activity of Euphorbia hirta Linn. in streptozotocin-induced diabetic mice. Indian J Nat Prod Resour 2010;1:200-3.

10. Rathi Sre PR, Sheila T, Kandasamy M. Phytochemical screening and "in vitro" antioxidant activity of methanolic root extract of Erythrinaindica. Asian Pac J Trop Biomed 2012;2:1696-700.

11. Udayan PS. Tinosporasinensis (Lour.) Merr. From sickupara, kollohills forest, namakkal district tamilnadu. Zoo's Print J 2004:19:1622-3.

12. Singleton V L, Rossi JA. Colorimetry of total phenolics with phosphomolybdic-phosphotungstic acid reagents. Am J Enol Vitic 1965;16:144-58

13. Ordonez AAL, Gomez JG, Vattuone MA, Isla MI. Antioxidant activities of Sechiumedule (Jacq.) swart extracts. Food Chem 2006;97:452-8

14. Kumaran A, Karunakaran RJ. Antioxidant and free radical scavenging activity of an aqueous extract of Coleus aromaticus. Food Chem 2006;97:109-14.

15. Oyaizu M. Studies on the product on browning reaction prepared from glucose amine. Japan J Nutr 1986;44:307-15.

16. Blois MS. Antioxidant determination by the use of-of a stable free radical. Nature 1958;181:1199-200.

17. Re R, Pellegrini N, Proteggente A, Pannala A, Yang M, Rice-Evans C. Antioxidant activity applying an improved ABTS radical cation decolorization assay. Free Radical Bio Med 1999;26:1231-7.

18. Ali H, Houghton PJ, Soumyanath A. $\alpha$-amylase inhibitory activity of some Malaysian plants used to treat diabetes; with particular reference to phyllanthusamarus. J Ethnopharmacol 2006; 107:449-55.

19. Kim JS, Hyun TK, Kim MJ. The inhibitory effects of ethanol extract from sorghum, foxtail millet and proso millet on $\alpha$ glucosidase and $\alpha$-amylase activities. Food Chem 2011; 124:1647-51.
20. Shai LJ, Masoko P, Mokgotho MP, Magano SR, Mogale MA, Boaduo $\mathrm{N}$, et al. Yeast alpha-glucosidase inhibitory and antioxidant activities of six medicinal plants collected in Phalaborwa. South Afr J Bot 2010;76:465-70.

21. Chandrashekharaiah KS, Menaka N Bolaki, Gupta Shivani Sanjay, Aanchal Bathija, Murthy VK, Narayanaswamy M, Swamy NR. Anti-oxidant and anti-hyperglycemic properties of methanolic extracts of medicinal plants. Biosci Biotech Res Asia 2013;10:607-12.

22. Florence OJ, Adeolu AA, Anthony JA. Comparison of the nutritive value, antioxidant and antibacterial activities of Sonchus asper and Sonchus oleraceus. Rec Nat Prod 2011;5:29-42.

23. Pourmorad F, Hosseinimehr SJ, Shahabimajd N. Antioxidant activity, phenol and flavonoid contents of some selected Iranian medicinal plants. Afr J Biotechnol 2006;5:1142-5.

24. Koleva II, Van Beek TA, Linssen JPH, Groot AD, Evstatieva LN. Screening of plant extracts for antioxidant activity: a comparative study on three testing methods. Phytochem Anal 2002;13:8-17.

25. Paloma Michelle de Sales, Paula Monteiro de Souza, Luiz Alberto Simeoni, Pérola de Oliveira Magalhães, Dâmaris Silveira. $\alpha$-amylaseinhibitors: a review of raw material and isolated compounds from a plant source. J Pharm Pharm Sci 2012;15:141-83

26. Kunyanga CN, Imungi JK, Okoth MW, Biesalski HK, Vadivel V. Total phenolic content, antioxidant and antidiabetic properties of methanolic extract of raw and traditionally processed Kenyan indigenous food ingredients. LWT-Food Sci Technol 2012;45:269-76.

27. Mai TT, Thu NN, Tien PG, Van Chuyen N. Alpha-glucosidase inhibitory and antioxidant activities of Vietnamese edible plants and their relationships with polyphenol contents. J Nutr Sci Vitaminol (Tokyo) 2007;53:267-76.

28. Ramkumar KM, Thayumanavan B, Palvannan T, Rajaguru P. Inhibitory effect of Gymnema Montana leaves on $\alpha$-glucosidase activity and $\alpha$-amylase activity and their relationship with polyphenolic content. Med Chem Res 2010;19:948-61.

29. Zhenhua Yin, Wei Zhang, Fajin Feng, Yong Zhang, Wenyi Kang. $\alpha$-Glucosidase inhibitors isolated from medicinal plants. Food Sci Human Wellness 2014;3:136-74.

30. Manikandan R, Vijaya A, Muthumani GD. Phytochemical and in vitro anti-diabetic activity of methanolic extract of Psidiumguajavaleaves. Int J Curr Microbiol Appl Sci 2013;2:15-9.

\section{How to cite this article}

- Anindita Banerjee, Bithin Maji, Sandip Mukherjee, Kausik Chaudhuri, Tapan Seal. In vitro anti-diabetic and antioxidant activities of ethanol extract of Tinospora sinensis. Int J Curr Pharm Res 2017;9(2):42-47. 